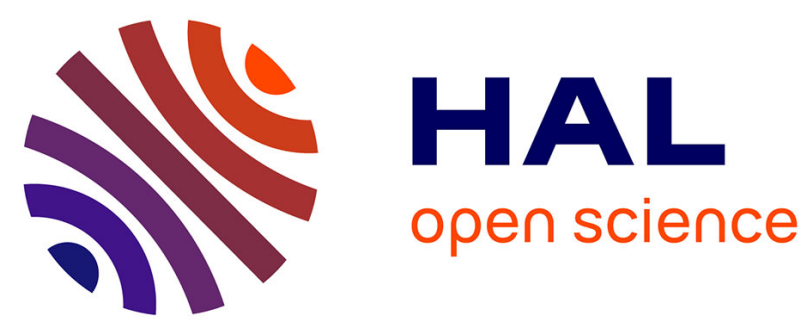

\title{
Game of Words: prototype of a digital game focusing on oral production (and comprehension) through asynchronous interaction
}

\author{
Mathieu Loiseau, Racha Hallal, Pauline Ballot, Ada Gazidedja
}

\section{To cite this version:}

Mathieu Loiseau, Racha Hallal, Pauline Ballot, Ada Gazidedja. Game of Words: prototype of a digital game focusing on oral production (and comprehension) through asynchronous interaction. Salomi Papadima-Sophocleous; Linda Bradley; Sylvie Thouësny. CALL communities and culture short papers from EUROCALL 2016, Research-publishing.net, pp.284-289, 2016, 978-1-908416-45-2. 10.14705/rpnet.2016.eurocall2016.576 . halshs-01422327

\section{HAL Id: halshs-01422327 \\ https://shs.hal.science/halshs-01422327}

Submitted on 25 Dec 2016

HAL is a multi-disciplinary open access archive for the deposit and dissemination of scientific research documents, whether they are published or not. The documents may come from teaching and research institutions in France or abroad, or from public or private research centers.
L'archive ouverte pluridisciplinaire HAL, est destinée au dépôt et à la diffusion de documents scientifiques de niveau recherche, publiés ou non, émanant des établissements d'enseignement et de recherche français ou étrangers, des laboratoires publics ou privés.

\section{(ㅇ)(1) $\$$}

Distributed under a Creative Commons Attribution - NonCommercial - NoDerivatives $\mid 4.0$ 


\title{
Game of Words: prototype of a digital game focusing on oral production (and comprehension) through asynchronous interaction
}

\author{
Mathieu Loiseau ${ }^{1}$, Racha Hallal2 ${ }^{2}$, \\ Pauline Ballot ${ }^{3}$, and Ada Gazidedja ${ }^{4}$
}

\begin{abstract}
In this paper, we present a learning game designed according to a strategy focusing on favouring the learners' playful attitude. The game's modalities pertain to what we might call 'guessing games'. The chosen avatar of such guessing games both exists as learning and Commercial Off The Shelf (COTS) board games. We explain in this paper how we adapted them into a digital game, taking decisions prompted by language learning but also addressing technical and contextual issues. We resort to the literature on communicative strategies to justify the expected outcomes of using this game and describe certain feedback stemming from self enrolling user tests performed by language teachers in early 2016 . We conclude by describing the next steps in this research.
\end{abstract}

Keywords: game based learning, strategic competence, oral production, oral comprehension.

\section{Guessing game based learning ${ }^{5}$}

Many researchers see various advantages in resorting to game based learning. In the field of language learning, some see in games an opportunity to overcome excessive self consciousness impeding involvement in tasks (Villez, 2006). Yet the emergence of a playful attitude considered productive in games in terms of (language) learning is far from being systematic in learning games (Lavigne,

\footnotetext{
1. Université Grenoble Alpes, LIDILEM, Innovalangues, Grenoble, France; mathieu.loiseau@univ-grenoble-alpes.fr

2. Télécom SudParis - Institut Mines-Télécom, Paris, France; racha.hallal@telecom-sudparis.eu

3. Claroline.com, Grenoble, France; pauline.ballot@claroline.com

4. Università di Bologna, Innovalangues, Bologna, Italy; ada.gazidedja@studio.unibo.it

5. Our approach is consistent across projects, see Loiseau et al. (2016, this volume), for more bibliographic references.
}

How to cite this article: Loiseau, M., Hallal, R., Ballot, P., \& Gazidedja, A. (2016). Game of Words: prototype of a digital game focusing on oral production (and comprehension) through asynchronous interaction. In S. Papadima-Sophocleous, L. Bradley \& S. Thouësny (Eds), CALL communities and culture-short papers from EUROCALL 2016 (pp. 284-289). Researchpublishing.net. https://doi.org/10.14705/rpnet.2016.eurocall2016.576 
2013). The metaphor of 'chocolate coated broccoli' for serious games has even been used in various publications (see Söbke, Bröker, \& Kornadt, 2013). To avoid this type of reaction, we have adapted Söbke et al.'s (2013) design suggestions. Though they advocate for directly using COTS, they acknowledge that COTS that can be enriched with educational content are rare (Söbke et al., 2013). Consequently, we have chosen to design games by resorting to metaludic rules (pertaining to a game genre) (Silva, 1999) of successful games. Additionally, we have so far designed games that offer the student the possibility to repeat games (in a casual game manner) rather than resorting to an elaborate one time play scenario.

In this paper, we aim to introduce a game prototype designed and developed within the GAMER work package of the Innovalangues project. We focus on Game of Word $^{6}$, which could be described as a guessing game. The metaludic rules are as follows:

- one player/team holds a knowledge (often a word, sometimes an expression or a person);

- one player/team ought to guess this knowledge;

- specific modalities are defined as to how this knowledge is to be transmitted between the two entities.

Depending on the said modalities, such communication games seem to be a way by which learners might be led to work on the appropriate use of the 'strategic competence'. Each such set of modalities defines another avatar of guessing games.

\section{Strategic competence}

Canale and Swain (1980) define the strategic competence as "verbal and nonverbal communication strategies that may be called into action to compensate for breakdowns in communication due to performance variables or to insufficient competence" (p. 30). Many authors concur in dividing those strategies into two categories (sometimes bearing different names depending on the author): message adjustment strategies and resource expansion strategies (CECRL, 2000; Dörnyei \& Thurrell, 1991; Mariani, 1994).

6. http://gamer.innovalangues.net/gameofwords / and https:/github.com/InnovaLangues/GameOfWord 
While the Common European Framework of Reference for languages (CEFR or CECR in French) does not formally define the strategic competence, it stresses the importance of strategies (be they communicative or learning strategies) (CECRL, 2000), thus highlighting the point made earlier by Dörnyei and Thurrell (1991). Additionally, Mariani (1994) mentions that the acquisition of resource expansion strategies are by definition more profitable to the learner, as they do not rely on their avoiding difficulties.

In this paper, we focus on verbal production strategies as they are at the core of our game's ludic structures, and more precisely on resource expansion strategies.

\section{Our prototype}

The avatar of guessing games we chose for the first version of this prototype is based on the well-known modalities of $\operatorname{taboo}^{7}$ : in order to convey their knowledge (a word) the first team can neither use that word, nor a list of words deemed by the designer of the game as useful to describe the word. By essence, these rules force the learner to find ways to have other players find a specific word without ever mentioning it. Indeed one can link the task performed in the game to the one used by Paribakht (1985) in her experiment meant to establish a taxonomy, where she would ask the student to communicate a lexical item (concrete or abstract) to a (native) student, without using the word.

The chosen rules are also consistent with some of Dörnyei and Thurrell's (1991) suggestions for strategic competence focused learning tasks. These rules are also consistent with games used in class by teachers of English, French and Italian as foreign languages, according to interviews we performed.

One of the advantages of using a digital game is that it can be used both in and out of the classroom, but it also comes with constraints, especially when devising a first prototype. We implemented our prototype according to two such constraints:

- the game was to focus on oral production and comprehension;

- the game is asynchronous in its modalities.

7. Designed by Hersch \& Bougrèle (1990), see https://en.wikipedia.org/wiki/Taboo_(game). 
The oral component is a priority due to its relative under-representation in CALL, but we only handle audio, both to make the development faster and because video would require a lot more space on the server. But this discards one of the four approaches identified by Paribakht (1985) in her taxonomy, which is non-verbal (mime as opposed to linguistic, contextual, and conceptual approaches).

The asynchronous aspect rather emerged from the game mechanics. Such guessing games induce that three persons are required to make the game playable, which can be an issue. Using synchronous modalities, the lack of players can result in players spending most of their playing time waiting for other users. On the other hand, in asynchronous modalities, we can ensure that the player can have some activity anytime they connect. But the downside of this decision is that it cuts interaction down to the minimum, and needs to be orchestrated.

In a role playing game fashion, we associated each role to a trade: druid, oracle, and augur (cf. Figure 1). The oracle's role is to record a riddle meant to allow other players to find the explained word ('Coffee' in Figure 1) without using any word displayed on the 'card' provided (see 'Input' in Figure 1). The druid makes sure that the recording is technically audible and that the oracle did not use any forbidden word. Finally, if the recording is adequate, it is submitted to the augur whose goal is to interpret the oracle's riddle.

Figure 1. Roles, tasks and data lifecycle in Game of Words

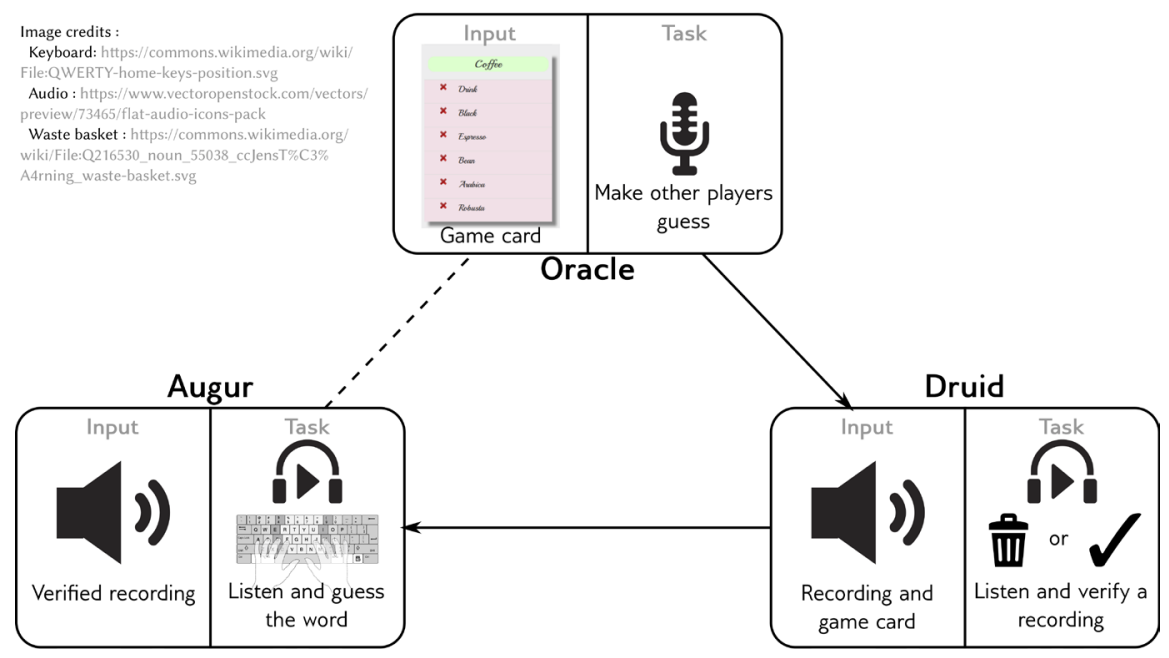


Each role is associated to a scoring category in order to motivate players to play all roles, as the playability of the game directly relies on people adopting every role. Indeed, if no one verifies, as a druid, that oracles follow the rules, there will never be recordings for augurs, and the oracle's activity will remain pointless. Yet to provide more game opportunities, a given recording can be served to various augurs.

Players can also earn druid points by creating new cards (a word to guess associated with one or more forbidden words ${ }^{8}$ ). Resorting to user generated content makes the game playable in any language that can be written using UTF-8 characters and verbalised (sign languages cannot be handled thus far, for instance).

\section{Experiments, future works and conclusion}

The first development cycle led to a testable game prototype. In order to prepare for the following iteration, a user test was set up with teachers and language students. The game was made available to the public and submitted to teachers and learners to use autonomously with no other guidance than a short explanation of the functionalities. Users could later fill a questionnaire. Qualitative analysis of our data allowed us to identify some bugs and to enrich the database with new 'game cards' created by teachers and learners. The test also raised some specific needs of teachers to improve the functionalities: mainly to allow to delete content. As a learning task, one teacher had his student create cards to play later. In this process, he wanted to be able to validate the cards.

The resulting prototype is still in alpha stage, but playable, and we plan to carry out an experiment in the winter to both evaluate Game of Words from the standpoint of game structures - do the students adopt a playful attitude? What prevents them from acquiring it? - and of the strategies invoked. As such, we hope to collect enough recordings to compare the students' productions with existing strategic competence taxonomies.

These results will allow us to implement a first version of the game, which will in turn allow the evaluation of the learning outcomes of the game. More game modes might be included. Some modes might offer new knowledge transmission rules, based on other such activities (Dörnyei \& Thurrell, 1991) or exploring multimodality. Finally, other game modes might build on L1 based strategies and the growing body of literature regarding intercomprehension.

8. The number of forbidden words varies depending on the level of the player (as teachers we interviewed do in class). 


\section{Acknowledgements}

We would like to thank the Innovalangues project for allowing this research and all those who contributed to it: Virginie Zampa, Chloe Cimpello, Justine Reverdy, Maryam Nejat, David Graceffa, Benjamin Abrial, Arnaud Bey and all the teachers and learners who tried Game of Words.

\section{References}

Canale, M., \& Swain, M. (1980). Communicative approaches to second language teaching and testing. Applied Linguistics, 1(1), 1-47. https://doi.org/10.1093/applin/1.1.1

CECRL. (2000). Cadre européen commun de référence pour les langues: apprendre, enseigner, évaluer. (Conseil de la coopération culturelle - Comité de l'éducation - Division des langues vivantes, Ed.) (Édition française). Strasbourg ; Paris: Conseil de l'Europe. http:// medias.didierfle.com/media/contenuNumerique/007/4140016745.pdf

Dörnyei, Z., \& Thurrell, S. (1991). Strategic competence and how to teach it. ELTJ, 45(1), 16-23. https://doi.org/10.1093/elt/45.1.16

Lavigne, M. (2013). Pertinence et efficacité des serious games - Enquête de réception sur neuf serious games (S. Leleu-Merviel \& K. Zreik, Ed.). Revue des Interactions Humaines Médiatisées, 14(1), 99-123.

Loiseau, M. et al. (2016). Exploring learners' perceptions of the use of digital letter games for language learning: the case of Magic Word. In S. Papadima-Sophocleous, L. Bradley \& S. Thouësny (Eds), CALL communities and culture - short papers from EUROCALL 2016 (pp. 277-283). Research-publishing.net. https://doi.org/10.14705/rpnet.2016.eurocall2016.575

Mariani, L. (1994). Competenza strategica e interazione orale. In D. Corno \& M. G. Dandini (Eds), La voglia di insegnare (pp. 145-152). Presented in VIIIe colloque « teaching \& learning », Turin: Regione Piemonte Assessorato Istruzione. http://www.learningpaths.org/ Articoli/competenzastrategica.pdf

Paribakht, T. (1985). Strategic competence and language proficiency. Applied Linguistics, 6(2), 132-146. https://doi.org/10.1093/applin/6.2.132

Silva, H. (1999). Poétiques du jeu. La métaphore ludique dans la théorie et la critique littéraires françaises au XXe siècle. (Thèse). Université Paris 3 - Sorbonne Nouvelle, Paris. http:// lewebpedagogique.com/jeulangue/files/2011/01/PoetiquesLud.pdf

Söbke, H., Bröker, T., \& Kornadt, O. (2013). Using the master copy — Adding educational content to commercial video games. In P. Escudeiro \& C. V. de Carvalho (Eds), The Proceedings of The 7th European Conference on Games Based Learning (Vol. 2, pp. 521-530). Reading: Academic Conferences and Publishing International Limited. http://issuu.com/acpil/docs/ecgbl2013-issuu_vol_2 Villez, B. (2006). Objectifs spécifiques d'apprentissage en langues étrangères à l'Université. (Y. Ayme, Ed.). Cahiers pédagogiques, 448, 51-53. 


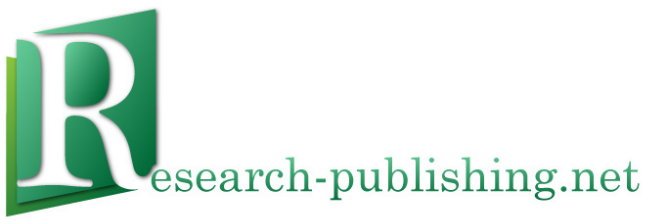

Published by Research-publishing.net, not-for-profit association Dublin, Ireland; Voillans, France, info@research-publishing.net

(C) 2016 by Editors (collective work)

(C) 2016 by Authors (individual work)

\section{CALL communities and culture - short papers from EUROCALL 2016 Edited by Salomi Papadima-Sophocleous, Linda Bradley, and Sylvie Thouësny}

Rights: All articles in this collection are published under the Attribution-NonCommercial -NoDerivatives 4.0 International (CC BY-NC-ND 4.0) licence. Under this licence, the contents are freely available online as PDF files (https://doi. org/10.14705/rpnet.2016.EUROCALL2016.9781908416445) for anybody to read, download, copy, and redistribute provided that the author(s), editorial team, and publisher are properly cited. Commercial use and derivative works are, however, not permitted.

\section{(9) $\Theta \Theta$}

Disclaimer: Research-publishing.net does not take any responsibility for the content of the pages written by the authors of this book. The authors have recognised that the work described was not published before, or that it is not under consideration for publication elsewhere. While the information in this book are believed to be true and accurate on the date of its going to press, neither the editorial team, nor the publisher can accept any legal responsibility for any errors or omissions that may be made. The publisher makes no warranty, expressed or implied, with respect to the material contained herein. While Research-publishing.net is committed to publishing works of integrity, the words are the authors' alone.

Trademark notice: product or corporate names may be trademarks or registered trademarks, and are used only for identification and explanation without intent to infringe.

Copyrighted material: every effort has been made by the editorial team to trace copyright holders and to obtain their permission for the use of copyrighted material in this book. In the event of errors or omissions, please notify the publisher of any corrections that will need to be incorporated in future editions of this book.

Typeset by Research-publishing.net

Cover design by (C) Easy Conferences, info@easyconferences.eu,www.easyconferences.eu

Cover layout by (c) Raphaël Savina (raphael@savina.net)

Photo "bridge" on cover by (C) Andriy Markov/Shutterstock

Photo "frog" on cover by (C) Fany Savina (fany.savina@gmail.com)

Fonts used are licensed under a SIL Open Font License

ISBN13: 978-1-908416-43-8 (Paperback - Print on demand, black and white)

Print on demand technology is a high-quality, innovative and ecological printing method; with which the book is never 'out of stock' or 'out of print'.

ISBN13: 978-1-908416-44-5 (Ebook, PDF, colour)

ISBN13: 978-1-908416-45-2 (Ebook, EPUB, colour)

Legal deposit, Ireland: The National Library of Ireland, The Library of Trinity College, The Library of the University of Limerick, The Library of Dublin City University, The Library of NUI Cork, The Library of NUI Maynooth, The Library of University College Dublin, The Library of NUI Galway.

Legal deposit, United Kingdom: The British Library.

British Library Cataloguing-in-Publication Data.

A cataloguing record for this book is available from the British Library.

Legal deposit, France: Bibliothèque Nationale de France - Dépôt légal: décembre 2016. 